\title{
The Entry Strategy in the Emerging Market: A Study of Overseas Investment in Vietnam
}

\author{
Weng-Kun Liu* \\ Department of International Business, Feng Chia University, Taiwan. \\ *Corresponding author: Tel.: +886-4-2451-7250; email: wkunliu@fcu.edu.tw \\ Manuscript submitted November 10, 2016; accepted March 5, 2017. \\ doi.: 10.17706/ijeeee.2017.7.2.91-99
}

\begin{abstract}
With the trend of rapid globalization, Multinational Corporations (MNCs) are forced to search for overseas investment opportunities. The purpose of this study is to evaluate the entry strategy of investment in Vietnam by applying the Fuzzy Delphi Method and the Decision Making Trial and Evaluation Laboratory (DEMATEL) approaches. The entry strategy is a vital factor when MNCs vigorously develop the global investment strategies to enhance their international competitive advantages. This research attempts to evaluate the factors of entry strategy as the following four steps: First, this research attempts to construct the initial indicators of entry strategy. Second, a focus group of MNC experienced managers was established to discover the factors of entry strategy relating to the evaluation of overseas investment. Third, Fuzzy Delphi method was applied to select the important evaluation criteria. Finally, the DEMATEL approach is employed to explore the relevance among the factors of entry strategy. The research results indicate that the factor of culture has the highest degree of prominence, representing the degree of relationship between the factors of entry strategy. The factor of economy has the highest degree of relation, representing for the degree of effect and effected for the factors of entry strategy. The research results not only indicate the most important factors of dimension and criteria for entry strategy of investment, but also provide MNCs a valuable strategic guidance to carry out overseas investment successfully.
\end{abstract}

Key words: International entry modes, international entry strategy, internationalization motivation.

\section{Introduction}

Followed with the policy of free trade agreement and the trend of rapid globalization, the overseas expansion has become an important issue for Multinational Corporations (MNCs) to develop their overseas markets. The entry strategy therefore becomes a vital factor when MNCs vigorously invest across the borders and develop the global strategies to enhance their international competitive advantages in the world market. Decisions on entry strategy can widely influence business strategic planning and operational profit. MNCs use various entry strategy to expand global markets and consider numerous factors in determining the optimal entry mode for the investment. These factors will vary from industry to industry, but several important factors have to be considered, including the country's economy, market, policy, culture, and technology. The decision making of entry strategy is important for MNCs investment overseas. Thus, careful assessing for the investment environment and selecting a suitable entry mode are so important for the overseas investment. The decision criteria of entry strategy will be investigated when MNCs consider overseas investment. 


\section{The Conceptual Framework of the Research}

This research inclines to evaluate the entry strategy of investment in Vietnam as the following steps. First, this research attempts to construct the initial indicators of entry strategy. Second, a focus group of MNC managers with abundant experiences was established to evaluate the primary factors of entry strategy relating to the investment in Vietnam. Third, the important factors related to the evaluation criteria of entry strategies are selected by using Fuzzy Delphi method. Fourth, the important indicators of entry strategy are determined by applying the Decision Making Trial and Evaluation Laboratory (DEMATEL) approach, which is an analytical method of structural model used to clarify the essential of the problem. The research results not only provide MNCs a valuable reference to improve the model of entry strategy, but also provide appropriate strategic guidance to carry out overseas investment successfully.

\section{Literature Review}

\subsection{Internationalization Motivation}

When MNCs face their resource shortage in domestic market, they would search for overseas resources to substitute for the domestic shortage even if MNCs may meet many risks overseas (Root, 1987). Four internationalization motivations are proposed for MNCs to expand their overseas investment, including resource-seeking, customer orientation, market-seeking, and oligopolistic interaction [1].

Yip [2] identified several internationalization motivations, which drive MNCs to expand their multinational investment strategies. Five multinational investment strategies are proposed as follows:

1. Market-oriented: including common customer demands, global customers, global channels, transferable marketing and lead countries.

2. Competition-oriented: including high levels of export and import in a specific industry, the presence of competitors from different counties, interdependence of countries, and the transaction policies of competitors themselves.

3. Technology-oriented: including advances in the performance, capabilities of telecommunications and computerization and software.

4. Government-oriented: including favorable trade policies, compatible technical standards , common marketing regulations, government-owned competitors and host government policies

5. Cost-oriented: Matlay \& Flecher [3] divided internationalization motivation as two categories, one is internal motivation, the other one is external motivation. Internal motivation includes knowledge, competencies, skills, human resources development needs and internal financial resources. External motivation includes global networks and contacts, specific global marketing information, global distribution channels, economics conditions, availability of external sources of finance and risk associated with exports.

\subsection{International Entry Strategy}

Anderson \& Gatignon [4] indicated international entry strategy is an institutional arrangement, which effectively drive the MNCs expand overseas market. Deresky [5] showed that international entry strategy should enhance the international competitiveness, relieve the domestic market, and increase new market development. Previous researches proved that economy, policy, culture and language difference will affect the decision of entry strategy [6]-[8].

\subsection{International Entry Mode}

Root [9] found that entry modes can be divided into two parts: One is that the goods or services export to the target market; the other is that the resources were transferred to the target market. Due to the goods 
can be produced in the target market. The entry modes can be subdivided into the following three categories: export entry modes, contractual entry modes, and investment entry modes.

Refer to the above taxonomical approaches, this research summarized the structure of entry strategy as the following five dimensions: (1) culture, (2) policy, (3) technology, (4) market, and (5) economy.

\section{Investment Environment in Vietnam}

Although through several years of subdued growth and general macroeconomic instability, Vietnam has been transited from a central planned economy to dense populated developing society. Vietnam authorities had confirmed their commitments to strengthen modernized economy in recent years. In 2007, Vietnam became an official member of the World Trade Organization (WTO), which has created more competitive industrial industries in domestic markets. In 2010, Vietnam joined the Trans-Pacific Partnership Trade Agreement, which had caused agriculture share of economic output to shrink from $25 \%$ in 2000 to $22 \%$ in 2012 [10]. Meanwhile, economic growth is projected at 5.7\% in 2014 and 6.3\% in 2015 [11]. Vietnam is trying to enhance employment rate and increase industrial development in recent years. Foreign direct investment (FDI), which facilitated Vietnam's rapid growth rates during the middle of the last decade, had more or less stagnated in 2008-12, but now appears to be expanding at a brisker pace. FDI approvals jumped nearly 55\% in 2013, which means there is a good pipeline of projects to materialize in 2014-15.

As shown in Table 1, the real growth rate of Gross Domestic Product (GDP) is recorded as 5.3percent in 2014. According to the General Statistics Office of Vietnam, the export revenue of 2014 totaled 128.9 billion USD while import turnover of 2014 reached 121.4 billion USD, representing a trade surplus of 7.5 billion USD [12].

Table 1. Vietnam Economy Profile of 2014

\begin{tabular}{cc}
\hline Item & Data \\
\hline GDP/Official Exchange Rate & $\$ 170$ Billion \\
\hline GDP/Purchasing Power Parity & $\$ 358.9$ Billion \\
\hline GDP/Real Growth Rate & $5.3 \%$ \\
\hline GDP/Per Capita & $\$ 4,000$ \\
\hline Gross National Saving & $38.4 \%$ of GDP \\
\hline Labor force & 52.93 Million \\
\hline Unemployment Rate & $1.3 \%$ \\
\hline Public Debt & $48.2 \%$ of GDP \\
\hline Inflation Rate & $6.8 \%$ \\
\hline Industrial Production Growth Rate & $5 \%$ \\
\hline Exports & $\$ 128.9$ Billion \\
\hline Imports & $\$ 121.4$ Billion \\
\hline Trade Surplus & $\$ 7.5$ Billion \\
\hline Source: Indexmundi (2015) [13]
\end{tabular}

\section{Fuzzy Delphi Method}

The Delphi method aims to improve group decision making by seeking opinions without face-to-face interaction and is commonly described as "a method of systematic solicitation and collection of judgments on a particular topic through a set of carefully designed sequential questionnaires, interspersed with 
summarized information and feedback of opinions derived from earlier responses" [14], [15].

This study adopts the reformed Fuzzy Delphi Method (FDM) which is based on triangular fuzzy numbers. The FDM method was applied to select the entry strategy of overseas investment, because it not only solved the disadvantages resulting from the conventional Delphi Method, but also because its results would not easily be affected by extreme opinions. Finally, the procedure of adopting the Fuzzy Delphi Method to the structure of entry strategy for MNC overseas investment is described.

\section{Empirical Research Analysis}

\subsection{Applications of the Fuzzy Delphi Method}

A focus group method is employed to develop and construct the essential dimensions and criteria of entry strategy for MNC overseas investment. After constructing the structure of initial indicators of entry strategy, a focus group of 20 experts was established to participate in the survey and construct the structure of the entry strategy. After establishing the initial structure of criteria, the Fuzzy Delphi Method is developed to identify the important criteria of entry strategy.

The fuzzy weight number $\widetilde{\mathrm{W}}_{i j}$ could not be used for direct comparison. This study therefore employed the fuzzy mean and spread method, transforming the result into a crisp number of $A_{j}$.

The threshold of entry strategy criteria is set as $b=0.828$.

If $A_{j} \geq 0.828$, then the indicator of entry strategy should be selected;

If $A_{j}<0.828$, then the indicator of entry strategy should be deleted.

Table 2. The Criteria of Entry Strategy by Using Fuzzy Delphi Method

\begin{tabular}{|c|c|c|c|}
\hline Dimensions & & Criteria & $\begin{array}{l}\text { Crisp } \\
\text { Number }\end{array}$ \\
\hline \multirow{3}{*}{$\begin{array}{l}D_{1} \\
\text { Culture }\end{array}$} & $\mathrm{C}_{11}$ & Value & 0.838 \\
\hline & $\mathrm{C}_{12}$ & Managerial Capabilities & 0.841 \\
\hline & $\mathrm{C}_{13}$ & Marketing & 0.845 \\
\hline \multirow{4}{*}{$\begin{array}{l}\mathrm{D}_{2} \\
\text { Policy }\end{array}$} & $\mathrm{C}_{21}$ & Currency Stability & 0.842 \\
\hline & $\mathrm{C}_{22}$ & Labor Laws & 0.852 \\
\hline & $\mathrm{C}_{23}$ & Tariff Policy & 0.845 \\
\hline & $\mathrm{C}_{24}$ & Attitudes of Government Officials & 0.835 \\
\hline \multirow{5}{*}{$\begin{array}{l}D_{3} \\
\text { Technology }\end{array}$} & $\mathrm{C}_{31}$ & Product Difference & 0.822 \\
\hline & $\mathrm{C}_{32}$ & $\mathrm{R} \& \mathrm{D}$ & 0.853 \\
\hline & $\mathrm{C}_{33}$ & Equipment Promoting & 0.810 \\
\hline & $\mathrm{C}_{34}$ & Know-how & 0.826 \\
\hline & $\mathrm{C}_{35}$ & Skilled Labor & 0.847 \\
\hline \multirow{4}{*}{$\begin{array}{l}\mathrm{D}_{4} \\
\text { Market }\end{array}$} & $\mathrm{C}_{41}$ & Market Size & 0.848 \\
\hline & $\mathrm{C}_{42}$ & Industry Incentives & 0.848 \\
\hline & $\mathrm{C}_{43}$ & Trading Experience & 0.839 \\
\hline & $\mathrm{C}_{44}$ & Competition & 0.839 \\
\hline \multirow{4}{*}{$\begin{array}{l}D_{5} \\
\text { Economy }\end{array}$} & $\mathrm{C}_{51}$ & Marketing scale & 0.849 \\
\hline & $\mathrm{C}_{52}$ & Business Practice & 0.845 \\
\hline & $\mathrm{C}_{53}$ & Gross Industry Production & 0.855 \\
\hline & $\mathrm{C}_{54}$ & Attainability of Fund & 0.841 \\
\hline
\end{tabular}


Most of the indicators in these five dimensions are retained. However, three criteria are selected in the dimension of culture $\left(\mathrm{D}_{1}\right)$, including Value $\left(\mathrm{C}_{11}\right)$, Managerial Capabilities $\left(\mathrm{C}_{15}\right)$, and Marketing $\left(\mathrm{C}_{16}\right)$. Four criteria are selected in the dimension of policy $\left(\mathrm{D}_{2}\right)$, including Currency stability $\left(\mathrm{C}_{21}\right)$, Labor laws $\left(\mathrm{C}_{22}\right)$, Tariff policy $\left(\mathrm{C}_{23}\right)$, and Attitudes of government officials $\left(\mathrm{C}_{24}\right)$. Five criteria are selected in the dimension of technology $\left(\mathrm{D}_{3}\right)$, including Product difference $\left(\mathrm{C}_{31}\right)$, $\mathrm{R} \& \mathrm{D}\left(\mathrm{C}_{32}\right)$, Equipment promoting $\left(\mathrm{C}_{33}\right)$, Know-how $\left(\mathrm{C}_{34}\right)$, and Skilled labor $\left(\mathrm{C}_{35}\right)$. Four criteria are selected in the dimension of market $\left(\mathrm{D}_{4}\right)$, including Market size $\left(\mathrm{C}_{41}\right)$, Industry incentives $\left(\mathrm{C}_{42}\right)$, Trading experience $\left(\mathrm{C}_{43}\right)$ and Competition $\left(\mathrm{C}_{44}\right)$. Finally, four criteria are selected in the dimension of economy $\left(\mathrm{D}_{5}\right)$, including Marketing scale $\left(\mathrm{C}_{51}\right)$, Business practice $\left(\mathrm{C}_{52}\right)$, Gross industry production $\left(\mathrm{C}_{53}\right)$, and Attainability of fund $\left(\mathrm{C}_{54}\right)$. The calculated result of the Fuzzy Delphi Method is obtained. As shown in Table 2, after deleting the above 15 less important criteria, total 35 initial criteria of entry strategy are reduced to 20 criteria.

\subsection{Measurement of Dematel Method}

The total influence given and received on dimensions was constructed by the $d_{i}$ and $r_{i}$ in the total direct-influence matrix $T$ in Table 3.

Tzeng, Chiang, and Li [16] demonstrated that $\left(d_{i}+r_{i}\right)$ represents the degree of relationship between the factors, meaning "prominence". As shown in Table 4, $\mathrm{D}_{1}$ (Culture) has the highest degree of prominence $\left(d_{i}+r_{i}\right)$. The ranking of prominence is listed from the highest to the least value as follows: $D_{1}(C u l t u r e), D_{3}$ (Technology), $\mathrm{D}_{4}$ (Market), $\mathrm{D}_{2}$ (Policy), and $\mathrm{D}_{5}$ (Economy).

Table 3. The Total Influence Given / Received for Dimensions

\begin{tabular}{llllclc}
\hline Dimensions & $\mathbf{d}$ & $\mathbf{r}$ & $\mathbf{d + r}$ & Rank & $\mathbf{d}-\mathbf{r}$ & Rank \\
\hline $\mathbf{D}_{\mathbf{1}}$ & 3.14 & 3.25 & 6.39 & $\mathbf{1}$ & -0.11 & $\mathbf{4}$ \\
\hline $\mathbf{D}_{\mathbf{2}}$ & 3.20 & 3.05 & 6.25 & $\mathbf{4}$ & 0.15 & $\mathbf{3}$ \\
\hline $\mathbf{D}_{\mathbf{3}}$ & 3.07 & 3.27 & 6.34 & $\mathbf{2}$ & -0.20 & $\mathbf{5}$ \\
\hline $\mathbf{D}_{\mathbf{4}}$ & 3.26 & 3.04 & 6.30 & $\mathbf{3}$ & 0.22 & $\mathbf{2}$ \\
\hline $\mathbf{D}_{\mathbf{5}}$ & 3.21 & 2.97 & 6.18 & $\mathbf{5}$ & 0.24 & $\mathbf{1}$ \\
\hline
\end{tabular}

Comparatively, $\left(d_{i}-r_{i}\right)$ presents the degree of effect and effected for the factors, meaning "relation". As shown in Table 3, $D_{5}$ (Economy) has the highest degree of effect $\left(d_{i}-r_{i}\right)$. The ranking of relation is listed from the highest to the least value as follows: $\mathrm{D}_{5}$ (Economy), $\mathrm{D}_{4}$ (Market), $\mathrm{D}_{2}$ (Policy), $\mathrm{D}_{1}$ (Culture), and $\mathrm{D}_{3}$ (Technology).

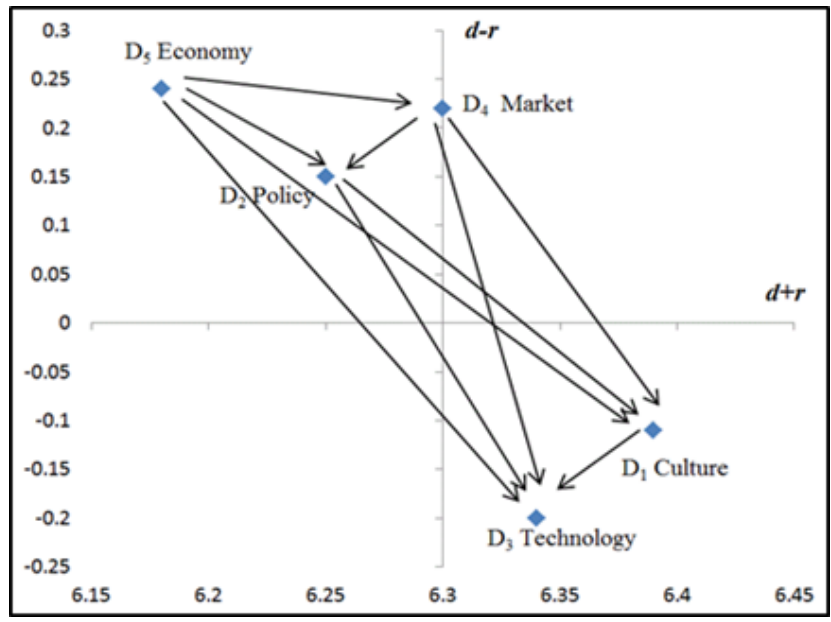

Fig. 1. The impact-relations-map of relations within dimensions of the entry strategy. 
As shown in Fig. 1, dimension $D_{5}$ affects the other four dimensions: $D_{4}, D_{1}, D_{3}$, and $D_{2}$ $\left(D_{5} \rightarrow\left\{D_{4}, D_{1}, D_{3}, D_{2}\right\}\right)$. From these influential relationships, MNC should first improve $D_{5}$ (Economy), then the other four dimensions $\mathrm{D}_{4}$ (Market), $\mathrm{D}_{1}$ (Culture), $\mathrm{D}_{3}$ (Technology), and $\mathrm{D}_{2}$ (Policy) will be improved.

Dimension $D_{4}$ affects dimension $D_{1}$ and $D_{3}\left(D_{4} \rightarrow\left\{D_{1}, D_{3}\right\}\right)$. MNC should improve $D_{4}$ (Market), then the other two dimensions: $\mathrm{D}_{1}$ (Culture) and $\mathrm{D}_{3}$ (Technology) will be improved.

Dimension $\mathrm{D}_{2}$ affects dimension $\mathrm{D}_{1}$ and $\mathrm{D}_{3}\left(\mathrm{D}_{4} \rightarrow\left\{\mathrm{D}_{1}, \mathrm{D}_{3}\right\}\right)$. MNC should improve $\mathrm{D}_{2}$ (Infrastructure), then the other two dimensions: $\mathrm{D}_{1}$ (Culture) and $\mathrm{D}_{3}$ (Technology) will be improved.

Dimension $D_{1}$ affects dimension $D_{3}\left(D_{1} \rightarrow\left\{D_{3}\right\}\right)$. MNC should improve $D_{1}$ (Culture), then the other dimension: $\mathrm{D}_{3}$ (Technology) will be improved.

Table 4. The Total Influence Given / Received for Criteria

\begin{tabular}{|c|c|c|c|c|c|c|c|}
\hline Dimension & Criteria & $\mathrm{d}$ & $r$ & $d+r$ & Rank & $d-r$ & Rank \\
\hline \multirow[t]{3}{*}{$\overline{D_{1}}$} & $\mathrm{C}_{11}$ & 1.77 & 1.70 & 3.47 & 3 & -0.07 & 2 \\
\hline & $\mathrm{C}_{12}$ & 1.83 & 1.75 & 3.58 & 1 & -0.08 & 3 \\
\hline & $\mathrm{C}_{13}$ & 1.79 & 1.74 & 3.53 & 2 & 0.05 & 1 \\
\hline \multirow[t]{4}{*}{$\overline{D_{2}}$} & $\mathrm{C}_{21}$ & 2.32 & 2.28 & 4.60 & 2 & 0.04 & 2 \\
\hline & $\mathrm{C}_{22}$ & 2.34 & 2.30 & 4.64 & 1 & 0.03 & 3 \\
\hline & $\mathrm{C}_{23}$ & 2.27 & 2.22 & 4.48 & 4 & 0.05 & 1 \\
\hline & $\mathrm{C}_{24}$ & 2.27 & 2.26 & 4.54 & 3 & 0.01 & 4 \\
\hline \multirow[t]{5}{*}{$\overline{D_{3}}$} & $\mathrm{C}_{31}$ & 3.20 & 2.86 & 6.06 & 5 & 0.33 & 1 \\
\hline & $\mathrm{C}_{32}$ & 3.01 & 3.27 & 6.28 & 1 & -0.26 & 5 \\
\hline & $\mathrm{C}_{33}$ & 3.08 & 3.13 & 6.21 & 2 & -0.06 & 3 \\
\hline & $\mathrm{C}_{34}$ & 3.07 & 3.05 & 6.13 & 4 & 0.02 & 2 \\
\hline & $\mathrm{C}_{35}$ & 3.03 & 3.12 & 6.15 & 3 & -0.09 & 4 \\
\hline \multirow[t]{4}{*}{$\mathbf{D}_{4}$} & $\mathrm{C}_{41}$ & 2.12 & 2.06 & 4.18 & 4 & 0.06 & 2 \\
\hline & $\mathrm{C}_{42}$ & 2.15 & 2.06 & 4.21 & 3 & 0.09 & 1 \\
\hline & $\mathrm{C}_{43}$ & 2.12 & 2.20 & 4.32 & 2 & -0.08 & 4 \\
\hline & $\mathrm{C}_{44}$ & 2.14 & 2.18 & 4.33 & 1 & -0.04 & 3 \\
\hline \multirow[t]{4}{*}{$\mathbf{D}_{5}$} & $\mathrm{C}_{51}$ & 1.67 & 1.64 & 3.30 & 1 & 0.03 & 2 \\
\hline & $\mathrm{C}_{52}$ & 1.64 & 1.63 & 3.25 & 2 & 0.01 & 3 \\
\hline & $\mathrm{C}_{53}$ & 1.48 & 1.44 & 2.91 & 4 & 0.04 & 1 \\
\hline & $\mathrm{C}_{54}$ & 1.59 & 1.66 & 3.25 & 3 & -0.07 & 4 \\
\hline
\end{tabular}

As shown in Table 4, within dimension of Culture $\left(D_{1}\right), C_{12}$ (Managerial capabilities) has the highest degree of prominence $\left(d_{i}+r_{i}\right)=3.58$, which represents the degree of relationship among the criteria of entry strategy. The top three criteria for the degree of prominence are ranked in order as follows: $\mathrm{C}_{12}$ (Managerial capabilities), $\mathrm{C}_{13}$ (Marketing) and $\mathrm{C}_{11}$ (Value). Comparatively, $\mathrm{C}_{13}$ (Marketing) has the highest 
value of effect $\left(\mathrm{d}_{\mathrm{i}}-\mathrm{r}_{\mathrm{i}}\right)=0.05$, which demonstrates that $C_{13}$ affects the other two criteria $C_{11}$ and $C_{12}$. That is, MNC should first improve $C_{13}$ (Marketing), then the other two criteria: $C_{11}$ (Value) and $C_{12}$ (Managerial capabilities) will be improved.

Within dimension of Policy $\left(D_{2}\right), C_{22}$ (Labor laws) has the highest degree of prominence $\left(d_{i}+r_{i}\right)=4.64$, which represents the degree of relationship among the criteria of entry strategy. The top four criteria for the degree of prominence are ranked in order as follows: $\mathrm{C}_{22}$ (Labor laws), $\mathrm{C}_{21}$ (Currency stability), $\mathrm{C}_{24}$ (Attitudes of government officials), and $\mathrm{C}_{23}$ (Tariff policy). Comparatively, $\mathrm{C}_{23}$ (Tariff policy) has the highest value of effect $\left(\mathrm{d}_{\mathrm{i}}-\mathrm{r}_{\mathrm{i}}\right)=0.05$, which demonstrates that $C_{23}$ affects the other three criteria $C_{21}, C_{22}$, and $C_{24}$. That is, MNC should first improve $\mathrm{C}_{23}$ (Tariff policy), then the other three criteria: $\mathrm{C}_{21}$ (Currency stability), $\mathrm{C}_{22}$ (Labor laws), and $\mathrm{C}_{24}$ (Attitudes of government officials) will be improved.

Within dimension of Technology $\left(D_{3}\right), C_{32}(R \& D)$ has the highest degree of prominence $\left(d_{i}+r_{i}\right)=6.28$, which represents the degree of relationship among the criteria of entry strategy. The top five criteria for the degree of prominence are ranked in order as follows: $\mathrm{C}_{32}$ (R\&D), $\mathrm{C}_{33}$ (Equipment promoting), $\mathrm{C}_{35}$ (Skilled labor), $\mathrm{C}_{34}$ (Know-how), and $\mathrm{C}_{31}$ (Product difference). Comparatively, $\mathrm{C}_{31}$ (Product difference) has the highest degree of effect $\left(\mathrm{d}_{\mathrm{i}}-\mathrm{r}_{\mathrm{i}}\right)=0.33$, which demonstrates that $C_{31}$ affects the other four criteria $C_{32}, C_{33}$, $C_{34}$, and $C_{35}$. That is, MNC should first improve $C_{31}$ (Product difference), then the other four criteria: $C_{32}$ (R\&D), $\mathrm{C}_{33}$ (Equipment promoting), $\mathrm{C}_{34}$ (Know-how), and $\mathrm{C}_{35}$ (Skilled labor), will be improved.

Within dimension of Market $\left(D_{4}\right), C_{44}$ (Competition) has the highest degree of prominence $\left(d_{i}+r_{i}\right)=4.33$, which represents the degree of relationship among the criteria of entry strategy. The top four criteria for the degree of prominence are ranked in order as follows: $\mathrm{C}_{44}$ (Competition), $\mathrm{C}_{43}$ (Trading experience), $\mathrm{C}_{42}$ (Industry incentives), and $\mathrm{C}_{41}$ (Market size). Comparatively, $\mathrm{C}_{42}$ (Administrative efficiency) has the highest value of effect $\left(\mathrm{d}_{\mathrm{i}}-\mathrm{r}_{\mathrm{i}}\right)=0.09$, which demonstrates that $C_{42}$ affects the other three criteria $C_{41}, C_{43}$, and $C_{44}$. That is, MNC should first improve $\mathrm{C}_{42}$ (Administrative efficiency), then the other three criteria: $\mathrm{C}_{41}$ (Market size), $\mathrm{C}_{43}$ (Trading experience), and $\mathrm{C}_{44}$ (Competition) will be improved.

Within dimension of Economy $\left(D_{5}\right), C_{51}$ (Marketing scale) has the highest degree of prominence $\left(d_{i}+r_{i}\right)=$ 3.30, which represents the degree of relationship among the criteria of entry strategy. The top four criteria for the degree of prominence are ranked in order as follows: $\mathrm{C}_{51}$ (Marketing scale), $\mathrm{C}_{52}$ (Business practice), $\mathrm{C}_{54}$ (Attainability of fund), and $\mathrm{C}_{53}$ (Gross industry production). Comparatively, $\mathrm{C}_{53}$ (Economies of scale) has the highest value of effect $\left(\mathrm{d}_{\mathrm{i}}-\mathrm{r}_{\mathrm{i}}\right)=0.04$, which demonstrates that $C_{53}$ affects the other three criteria $C_{51}, C_{52}$ and $C_{54}$. That is, MNC should first improve $\mathrm{C}_{53}$ (Gross industry production), then the other three criteria: $\mathrm{C}_{51}$ (Marketing scale), $\mathrm{C}_{52}$ (Business practice) and $\mathrm{C}_{54}$ (Attainability of fund) will be improved.

\section{Conclusion}

With the growth trend of globalization, MNCs are forced to develop their world expansion programs. The decision making of entry strategy becomes an important issue when MNCs expand overseas investment and markets vigorously. MNCs have to use appropriate research methods to evaluate various factors of entry strategy in determining the optimal overseas investment way. In this research, the evaluation indicators of entry strategy are selected by applying the Fuzzy Delphi method, which provides the evaluations of weights to choose total 20 vital criteria of entry strategy. The important indicators of entry strategy are determined by applying the Decision Making Trial and Evaluation Laboratory (DEMATEL) approach, which is an analytical method to clarify the essential of the decision making.

Based on the measurement of DEMATEL method, $\mathrm{D}_{1}$ (Culture) has the highest degree of prominence $\left(d_{i}+r_{i}\right)$. Also, $D_{5}$ (Economy) has the highest degree of effect $\left(d_{i}-r_{i}\right)$. Within dimension of Culture $\left(D_{1}\right), C_{12}$ (Managerial capabilities) has the highest degree of prominence and $\mathrm{C}_{13}$ (Marketing) has the highest value of effect. Within dimension of Policy $\left(D_{2}\right), C_{22}$ (Labor laws) has the highest degree of prominence and $C_{23}$ 
(Tariff policy) has the highest value of effect. Within dimension of Technology $\left(D_{3}\right), C_{32}(R \& D)$ has the highest degree of prominence and $\mathrm{C}_{31}$ (Product difference) has the highest degree of effect. Within dimension of Market $\left(\mathrm{D}_{4}\right), \mathrm{C}_{44}$ (Competition) has the highest degree of prominence and $\mathrm{C}_{42}$ (Administrative efficiency) has the highest value of effect. Finally, within dimension of Economy ( $\left.D_{5}\right), C_{51}$ (Marketing scale) has the highest degree of prominence and $\mathrm{C}_{53}$ (Economies of scale) has the highest value of effect. Those important dimensions and criteria could be applied by MNCs to evaluate the entry strategy of overseas investment and expand their world markets successfully.

\section{References}

[1] Dunning, J. H. (1992). Multinational Enterprise and the Global Economy. Wokingham, England: Assision-Wesley.

[2] Yip, G. S. (1989). Total Global Strategy: Managing for Worldwide Competitve Advantage. Eaglewood Cliffs, New Jersey: Prentice Hall.

[3] Matlay, H., \& Flecher, D. (2000). Globalization and strategic change: Some lessons from the UK small buiness sector. Strategic Change, 9, 437-449.

[4] Anderson, E., \& Gatignon, H. (1986). Modes of foreign entry: A transaction cost analysis and propositions. Journal of International Business Studies, 17(3), 1-26.

[5] Deresky, H. (1994). International Management: Managing across Borders and Cultures. Harper Collins College Publ., New York.

[6] Ambler, T., Styles, C., \& Xiucun, W. (1999). The effect of channel relationships and guanxi on the performance of inter-province export ventures in the People's Republic of China. International Journal of Research in Marketing 16, 75-87.

[7] Ebrahimi, B. P. (2000). Perceived strategic uncertainty and environmental scanning behavior of Hong Kong Chinese executives. Journal of Business Research, 49(1), 67-77.

[8] Dow, D.,\& Larimo, J. (2009). Challenging the conceptualization and measurement of distance and international experience in entry mode choice research. Journal of International Marketing, 17(2), 74-98.

[9] Root, F. R. (1987). Entry Strategies for International Markets, D.C. Health. MA: Lexington.

[10] Trading economics. (2014). Vietnam GDP Annual Growth Rate. Retrieved from the website: http://www.tradingeconomics.com/vietnam/gdp-growth-annual

[11] Country Profile of Vietnam. (2014). Business Environment. Retrieved from the website: http://www.lloyds.com/ /media/Files/The\%20Market/Tools\%20and\%20resources/New\%20Mark et\%20Intelligence/Country\%20Profiles/Asia\%20Pacific/vn_mi_2014_05_16_Country\%20Profile.pdf

[12] General Statistics Office of Vietnam. (2014). Statistical data, export and import of goods. Retrieved from the website: $\mathrm{http}: /$ www.gso.gov.vn/default_en.aspx?tabid=472\&idmid=3\&ItemID=14616

[13] Indexmundi. (2015). Vietnam Economy Profile 2015. Retrieved from the website: http://www.indexmundi.com/vietnam/\#Economy

[14] Delbecq, A. L., Van de Ven, A. H., \& Gustafson, D. H. (1975). Group Techniques for Program Planning. Glenview, IL: Scott, Foresman, and Co.

[15] Osborne, J., Collins, S., Ratcliffe, M., Millar, R., \& Duschl, R. (2003). What "ideasabout-science" should be taught in school science? A delphi study of the expert community. Journal of Research in Science Teaching, 40(7), 692-720.

[16] Tzeng, G. H., Chiang, C. H., \& Li, C. W. (2007). Evaluating intertwined effects in e-learning programs: A Novel hybrid MCDM model based on factor analysis and DEMATEL. Expert Systems with Applications, $32(4), 1028-1044$. 
Weng-Kun Liu is an associate professor at Feng Chia University in Taiwan. He majors in management administration and concentrates in the arena of international business management. He dedicates his interest in the researches of international Business management, leadership behavior, fuzzy theory, and decision making. He also devotes the researches of industry-academy cooperation to enhance the practical productionoutput. He served as Keynote Speaker of 2015 International Federation of Freight Forwarders Associations (FIATA) World Congress. He also served as Session Chair of 2017 International Conference on E-Education, E-Business, E-Management and E-Learning (IC4E). Moreover, he served as Program Chair of 2017 International conference on E-Business and Internet (ICEBI). Besides, he served as a referee of the International Journal of Human Resource Management (IJHRM) (SSCI) in 2016and Journal of Organizational Change Management (JOCM) (SSCI) in 2017. 